\title{
Addressing rural social exclusion in the developing world - exploring the role of African social purpose ventures
}

Book or Report Section

Littlewood, D. and Holt, D. (2015) Addressing rural social exclusion in the developing world - exploring the role of African social purpose ventures. In: Exploring rural enterprises: new perspectives on research, policy \& practice. Contemporary issues in entrepreneurship research, 4. Emerald, Bingley. ISBN 9781784411121 Available at http://centaur.reading.ac.uk/36918/

It is advisable to refer to the publisher's version if you intend to cite from the work. See Guidance on citing.

Publisher: Emerald

Publisher statement: This chapter is (c) Emerald Group Publishing and permission has been granted for this version to appear here. Emerald does not grant permission for this article to be further copied/distributed or hosted elsewhere without the express permission from Emerald Group Publishing 
Limited.

All outputs in CentAUR are protected by Intellectual Property Rights law, including copyright law. Copyright and IPR is retained by the creators or other copyright holders. Terms and conditions for use of this material are defined in the End User Agreement.

\section{www.reading.ac.uk/centaur}

\section{CentAUR}

Central Archive at the University of Reading

Reading's research outputs online 


\title{
Addressing rural social exclusion in the developing world - exploring the role of African social purpose ventures
}

\section{Dr David Littlewood (Henley Business School, University of Reading) Dr Diane Holt (Essex Business School, University of Essex)}

\begin{abstract}
Purpose

This chapter considers social purpose venturing as a vehicle for addressing social exclusion in the rural developing world, illustrated with reference to case examples across a range of East and Southern African countries.

Methodology/approach

Data was collected during in-depth case study research with social purpose ventures in various African countries. Qualitative research methods were primarily employed including interviews, stakeholder focus groups and observational research.

Findings

Six channels through which social purpose ventures contribute to tackling social exclusion amongst rural BoP communities are identified. These include ventures with the BoP as employees, producers, consumers, entrepreneurs, service users and shareholders. Characteristics for successful social purpose ventures are also discussed.
\end{abstract}

Research Implications

This chapter adds to knowledge in the field of social purpose venturing in the developing world. It identifies various channels through which such ventures help tackle rural social exclusion and also factors influencing their success.

Practical Implications

The chapter provides insights for practitioners and policy makers, particularly in relation to facilitating successful social purpose venturing.

Social implications

This chapter contributes to better practice in rural development in the Global South.

Originality/value of paper

This chapter provides insights relevant to academic and practitioner audiences. It addresses a subject area and region that has received limited attention. The chapter adds to knowledge on social purpose venturing in Africa.

Key Words: Rural Development; Africa; Social Exclusion

Categorization: Research Paper 


\section{Addressing rural social exclusion in the developing world - exploring the role of African social purpose ventures}

\section{Introduction}

In this chapter we identify and explore six channels through which social purpose ventures contribute to tackling social exclusion amongst the rural poor, illustrated through a range of case examples of African enterprises. Often the phrase 'Base of the Pyramid' or BoP is used to describe the 4 billion poor people globally living on less than US\$2.50 per day. In Africa it is estimated that $90 \%$ of the continent's rural population (over 430 million people) reside in this BoP segment (IFAD, 2010). Of the world's very poor people (defined by IFAD (2010) as those living on less than US\$1.25 a day) at least $70 \%$ are rural. In sub-Saharan Africa over 300 million people, equating to more than $60 \%$ of the rural population fall within this grouping (IFAD, 2010). Whilst income boundaries differ in terms of delineating the poor/absolute poor/ultra-poor across various statistical digests, in rural societies in the developing world the poorest members are often subsistence farmers and rely on survivalist activities to generate income.

Poor rural households in Africa and the wider developing world face numerous development challenges, including threats to agricultural production stemming from environmental degradation, climate change and water scarcity; the impacts of disease, including HIV/AIDS; financial insecurity, insecure employment and livelihoods, and difficulties in how and on what terms markets are accessed. In many instances these challenges reflect, and are compounded by, the economic, social and political exclusion and marginalisation of rural households, communities and regions (Bird, Hulme, Moore \& Shepherd, 2002). This exclusion can manifest in limited access to services which are frequently of a low standard, while livelihood and employment opportunities particularly in the formal sector are also often constrained. Access for rural dwellers to markets to sell products that they grow or make and to buy even basic necessities may be similarly restricted.

Innovative solutions are needed to these varied and complex rural development challenges. Social purpose venturing is increasingly looked upon as a key mechanism for tackling the kinds of 'wicked' sustainable development problems faced by rural communities in the developing world (Rittel and Weber, 1973). The enthusiasm currently surrounding these types of ventures is exemplified by the United Nations SEED Initiative which identifies alternative social and environmental ventures as critical for improving incomes, strengthening livelihoods, and tackling marginalisation and poverty in Africa, in ways that are sustainable and conserve natural resources and ecosystems (SEED and IISD, 2009). 
However despite the enthusiasm currently surrounding social purpose venturing, and its potential role in sustainable development in Africa, research in this area remains relatively fragmented and emergent. While there is a growing body of literature examining social purpose ventures in Africa (Thompson and Doherty, 2006; Kerlin, 2009), including some empirical case study research (Masendeke and Mugova, 2009), many questions and areas for further inquiry remain, including the routes by which successful social purpose ventures foster inclusion for the marginalised rural poor in societies through their enterprise activities.

\section{Social Purpose Venturing and the Rural BoP}

The 'development through enterprise' agenda has emerged over the last decade, informed by early work on the BoP and subsistence market place approaches to development by authors like CK Prahalad, Ted London and Stuart Hart. In their initial incarnations these approaches argued that the poor should be re-imagined as consumers, and it was suggested that there was 'a fortune at the bottom of the pyramid' for those companies, especially multinational corporations (MNCs), that could tailor their products or services to tap into this low income segment (Prahalad, 2004). These approaches drew criticism for their positioning and what some regarded as exploitation of the poor (Karani, 2007a; 2009), for transplanting unsustainable Western values and lifestyles to the developing world, and for an overemphasis on MNC involvement (Garette and Karnaani, 2010). However, recent discussions in this area have focussed on the need for the 'cocreation' of value (London and Hart, 2004, 2010; Hart 2005), with the poor incorporated as partners in venture design, product development and innovation, and implementation and production (London, 2007). Emphasis has also shifted away from MNCs, with growing interest in non-traditional multi-stakeholder partnerships for example collaboration between non-governmental organisations (NGOs), state actors, social enterprises, local community groups and micro-entrepreneurs. We discuss some of these types of partnerships within our case examples.

In this chapter the term 'social purpose venture' is used in favour of social enterprise, social business, or trading non-profit, to reflect the diverse, complex, hybrid landscape of social entrepreneurship and innovation in Africa. Social purpose ventures in Africa trade for social and/or environmental purposes. However they often have quite complex organisational forms, which may include both for profit and non-profit components, as well as drawing upon and leveraging the skills of multiple stakeholders and partners. Such ventures may comprise a standalone social enterprise or a 'proto social enterprise' NGO engaging in trading activity (Munoz, 2008). Alternatively they may be more profitoriented green businesses with an environmental mission selling green goods or services. In other instances they are inclusive businesses, drawing together and leveraging the skills and competencies of private sector investors, social enterprises and community businesses or cooperatives. Social purpose ventures are now recognised as key actors in and vehicles for reformed BoP approaches, both as partners for MNCs but also as 
independent initiators of BoP programmes and interventions (Wheeler, McKague, Thomson, Davies, Medalye \& Prada, 2005).

Many BoP ventures target the rural poor, with a growing body of literature documenting such initiatives. An example of a more traditional MNC-led BoP intervention is that by Hindustan Lever Ltd. (HLL), a subsidiary of Unilever PLC (Prahalad and Hart, 2002). In this initiative HLL responded to competition from a local firm Nirma Ltd, which began selling low cost detergent products in BoP markets, by developing and launching a new product called Wheel, with decentralised production, marketing and distribution channels more suited to this low income segment. Other examples of MNC-led BoP initiatives targeting the poor include the rapid growth in engagement in micro-lending to the BoP by leading commercial banks, inspired by the success of the Grameen Bank in Bangladesh (Karnani, 2007b). While MNCs are also now selling micro-insurance to rural BoP farmers, helping to reduce vulnerability to natural disasters and mitigate for longer term climate change risks (Manuamorn, 2007).

The co-creation of value and involvement of the poor as partners rather than just consumers and producers, has been described by some authors as 'BoP 2.0' (Simanis and Hart, 2008). This second generation of BoP approach emphasises 'creating a fortune with the BoP', and embedded structural innovation (Hart and London, 2010). Key components of such approaches include: the need for dialogue rather than consultation, better marrying of capabilities, embracing new sustainable technologies and for MNCs to develop more meaningful and direct relationships with both NGOs and BoP segments. An example BoP 2.0 venture involves the Indian tobacco giant ITC (formerly the Imperial Tobacco Company). ITC provides Indian micro-entrepreneurs with training and equipment helping them to establish E-choupal meeting places in rural communities. Through these E-choupal meeting places rural farmers gain better access to information on market conditions, prices, and potential buyers, increasing their bargaining power with middlemen purchasers called 'mandis' and enables them to get a fairer price for their soy crops, while also providing additional livelihoods for E-choupal entrepreneurs. Finally it benefits ITC which has been able to source agricultural commodities at more favourable prices (Hart and London, 2005). In a further example introduced by London (2009), the enterprise VisionSpring uses a microfranchising model to provide vision care to the poor. VisionSpring recruits 'vision entrepreneurs' giving each a kit - dubbed a 'business in a bag' - which contains an inventory of glasses, eye screening materials, marketing materials and sales forms. The entrepreneurs also receive training in how to conduct screenings, how to refer people to hospital, and how to run a small enterprise.

Increasing engagements by social enterprises, non-profit NGOs, cooperatives and wider social purpose ventures with low income groups through, and as initiators of, BoP programmes are recognised in the literature (Wheeler et al., 2005), as are their successes (Bronstein, 2004; London, 2007). For example Prahalad (2004) uses Jaipur Foot and Arvind Eye Care, both India based non-profits, as positive examples of BoP ventures. 
Another widely cited example is the for-profit social enterprise Honey Care Africa founded in 2001 in Nairobi Kenya (see Hart and London, 2005). They work in partnership with local communities, private sector and development actors to generate bee keeping livelihood opportunities for rural BoP farmers. Honey Care Africa procures and sells all of the equipment required to establish a beekeeping microenterprise to a development sector partner, which in turn leverages local social capital to provide microcredit financing to small farmers for the purchase of equipment. They provide farmers with training in bee keeping, and commit to purchasing all the honey they produce, guaranteeing them a regular income, and gaining a consistent supply of high-quality honey. The loan for equipment is gradually repaid through farmers' additional earnings (Hart and London, 2005). We resonance between the published case examples described above and the six channels for social inclusion identified in the case examples from our fieldwork in Zambia, Kenya, South Africa and Mozambique.

\section{Social Exclusion, Poverty and Development}

Social exclusion is a multidimensional concept, widely recognised in both developed and developing countries as playing a role in absolute and relative poverty, and in forms of marginalisation and disadvantage. Tackling various forms of social exclusion is an important underlying theme within the Millennium Development Goals (MDGs). Increasingly international institutions and national development agencies are also engaging with social exclusion (e.g. the World Bank, International Labour Organisation and the UK Department for International Development (DFID) have adopted social exclusion as a multidimensional framework in their work, integrating social exclusion issues into some of their programmes (Beall and lène Piron, 2009)). In this chapter, whilst the term social exclusion is used, its political and citizenship dimensions, and in particular its economic aspects are also recognised, especially given the often strong economic inclusion impacts social purpose ventures have, which in turn can be linked to improved social and poverty alleviation outcomes.

The term social exclusion is of relatively recent origin, and is primarily attributed to writing in the 1970s by René Lenoir (e.g. Lenoir, 1974/1989). Social exclusion has been linked to a wide range of social and economic problems amongst specific groups, who might be excluded from secure employment, property, land, citizenship, education, skills, respect or services (Silver, 1994). The intersection of social exclusion, poverty and deprivation has received considerable attention by authors such as Amartya Sen (2000), who highlights how the concept of social exclusion complements understandings of poverty as capability deprivation. Sen argues that social exclusion may be considered as directly part of capability poverty, whereby a capability deprivation (e.g. not being able to appear in public without shame) takes the form of social exclusion. However he also suggests that being excluded from social relations can lead to other kinds of deprivations, further limiting living opportunities (e.g. being excluded from the opportunity to be employed, to access markets or to gain credit can lead to deprivations like 
malnourishment or homelessness). For Sen, social exclusion is thus both a constitutive part of capability deprivation and an instrumental cause of capability failures. De Hann (2001) also distinguishes between passive exclusion where deprivation is caused without deliberate intent (e.g. through a weak economy) and active exclusion, (e.g. where certain groups, such as women, are deprived of access to services, employment opportunities, citizenship or political participation).

While discussions in this chapter are framed around the notion of social exclusion, some conceptual limitations are also recognised, as is its relationship with constrained or unfavourable inclusion. Hickey and Du Toit (2007) raise concerns about the relatively uncritical exportation of 'social exclusion talk' from policy debates in industrialised countries to poverty debates in 'developing' countries. The issue of what 'exclusion' means in different cultural context are highlighted by Du Toit (2004). An additional area of concern relates to agency, and the potential risk of portraying the excluded as helpless victims (Francis, 2006). Finally it may be argued that the underlying narrative shaping much social exclusion research is that 'inclusion' is intrinsically good, ignoring the potential for limited, inequitable or disempowering forms of inclusion, described as 'unfavourable inclusion' or 'adverse incorporation' (Hickey and Du Toit, 2007).

\section{Background to the Research}

This chapter draws upon research undertaken as part of a project examining social purposes ventures in Eastern and Southern Africa and their role in sustainable development and poverty alleviation (see www.trickleout.net). Here we draw upon data collected from a group of eight rural based social purpose venture case studies (see Table 1 for further detail). Qualitative methods of data collection were primarily employed including over 100 interviews and focus groups, as well as observational research and analysis of secondary materials such as annual reports.

\begin{tabular}{|l|l|l|}
\hline $\begin{array}{c}\text { Organisation } \\
\text { Name / Country }\end{array}$ & \multicolumn{1}{|c|}{ Activities } & \multicolumn{1}{|c|}{$\begin{array}{c}\text { Inclusion of the Rural } \\
\text { BoP }\end{array}$} \\
\hline Ecofinder Kenya & $\begin{array}{l}\text { Green energy technology; water and } \\
\text { sanitation; eco-cultural tourism; tree-based } \\
\text { Eenterprise; research and consultancy; social } \\
\text { marketing; training and capacity building; } \\
\text { advocacy; craft production, marketing and sale }\end{array}$ & $\begin{array}{l}\text { Entrepreneurs; } \\
\text { service } \\
\text { producers; customers; } \\
\text { employees (including } \\
\text { as volunteers) }\end{array}$ \\
\hline $\begin{array}{l}\text { Cookswell } \\
\text { Enterprises }\end{array}$ & $\begin{array}{l}\text { Production, sale and marketing of energy } \\
\text { efficient charcoal stoves, ovens and kilns; tree } \\
\text { planting; forestry related consultancy and }\end{array}$ & $\begin{array}{l}\text { Producers; customers } \\
\text { Kenya }\end{array}$ \\
\hline Tough Stuff Solar & $\begin{array}{l}\text { Global sale of solar products. Works with } \\
\text { commercial and non-profit partners on } \\
\text { Kenya (Uganda, }\end{array}$ & $\begin{array}{l}\text { Eusiness in a Box (BIAB) interventions with } \\
\text { customers }\end{array}$ \\
\hline
\end{tabular}




\begin{tabular}{|c|c|c|}
\hline $\begin{array}{l}\text { Malawi, } \\
\text { Zimbabwe, } \\
\text { Mauritius, } \\
\text { Madagascar, } \\
\text { Tanzania, } \\
\text { Ethiopia and } \\
\text { developed world) }\end{array}$ & $\begin{array}{l}\text { solar village entrepreneurs. Disaster relief } \\
\text { work for example in the aftermath of Haiti } \\
\text { Earthquake }\end{array}$ & \\
\hline $\begin{array}{l}\text { MICAIA Family of } \\
\text { Organisations } \\
\text { (including the } \\
\text { Mozambique } \\
\text { Honey Company, } \\
\text { Ndzou Camp and } \\
\text { other inclusive } \\
\text { business } \\
\text { ventures) } \\
\text { Mozambique }\end{array}$ & $\begin{array}{l}\text { Inclusive business ventures. Eco tourism, } \\
\text { Ndzou and Binga Camps and Mozambique } \\
\text { Ecotours; food and agricultural markets, fruits } \\
\text { of the forest processing business; the } \\
\text { Mozambique Honey Company, capacity } \\
\text { building of beekeepers; Baobab processing } \\
\text { business; research and consultancy }\end{array}$ & $\begin{array}{l}\text { Shareholders; } \\
\text { producers; }\end{array}$ \\
\hline $\begin{array}{l}\text { Mezimbite Forest } \\
\text { Centre } \\
\text { Mozambique }\end{array}$ & $\begin{array}{l}\text { Production high quality furniture and } \\
\text { homeware for export; jewellery; farming and } \\
\text { harvesting of natural products; treeplanting; } \\
\text { consultancy, research and education. }\end{array}$ & Employees; producers \\
\hline $\begin{array}{l}\text { The Mumwa } \\
\text { Craft Association } \\
\text { Zambia }\end{array}$ & $\begin{array}{l}\text { Craft production, marketing and sale; craft } \\
\text { training and capacity building; afforestation; } \\
\text { construction rural water wells; HIV/AIDS } \\
\text { interventions; biomass energy; fish farms; }\end{array}$ & $\begin{array}{l}\text { Producers; service } \\
\text { users }\end{array}$ \\
\hline $\begin{array}{l}\text { Tribal Textiles } \\
\text { Zambia }\end{array}$ & $\begin{array}{l}\text { Production of unique handpainted textile } \\
\text { products for domestic and international sale; } \\
\text { philanthropic donations to local charities and } \\
\text { schools. }\end{array}$ & Producers \\
\hline $\begin{array}{l}\text { The Book Bus } \\
\text { Zambia (Malawi } \\
\text { and other } \\
\text { developing } \\
\text { world) }\end{array}$ & $\begin{array}{l}\text { Book buses tour schools, hospitals and } \\
\text { orphanages to promote literacy; works in poor } \\
\text { rural communities and Maheba UNHCR } \\
\text { refugee camp; donation of books; library } \\
\text { development; school to school links; } \\
\text { volunteers pay to participate paying for } \\
\text { running costs. }\end{array}$ & Service users \\
\hline
\end{tabular}

Table 1 Case study social purpose ventures, their countries, areas of activity and inclusion channels 


\section{Social Purpose Ventures, Inclusion and the Rural BoP}

During the research we identified six channels through which social purposes ventures potentially contribute to tackling social exclusion amongst the rural BoP in Africa and the wider developing world.

\section{Inclusion through employment.}

An example of this route for addressing social exclusion is the for-profit Zambian rural social purpose venture Tribal Textiles based in the remote South Luangwa Valley. Artist, director and owner Gillie Lightfoot set up the business more than 20 years ago, to produce unique hand painted textile products decorated with African and contemporary designs (see Fig. 1). In a poor, geographically isolated region Tribal Textiles uses fair trade business practices to generate sustainable local employment within the BoP.

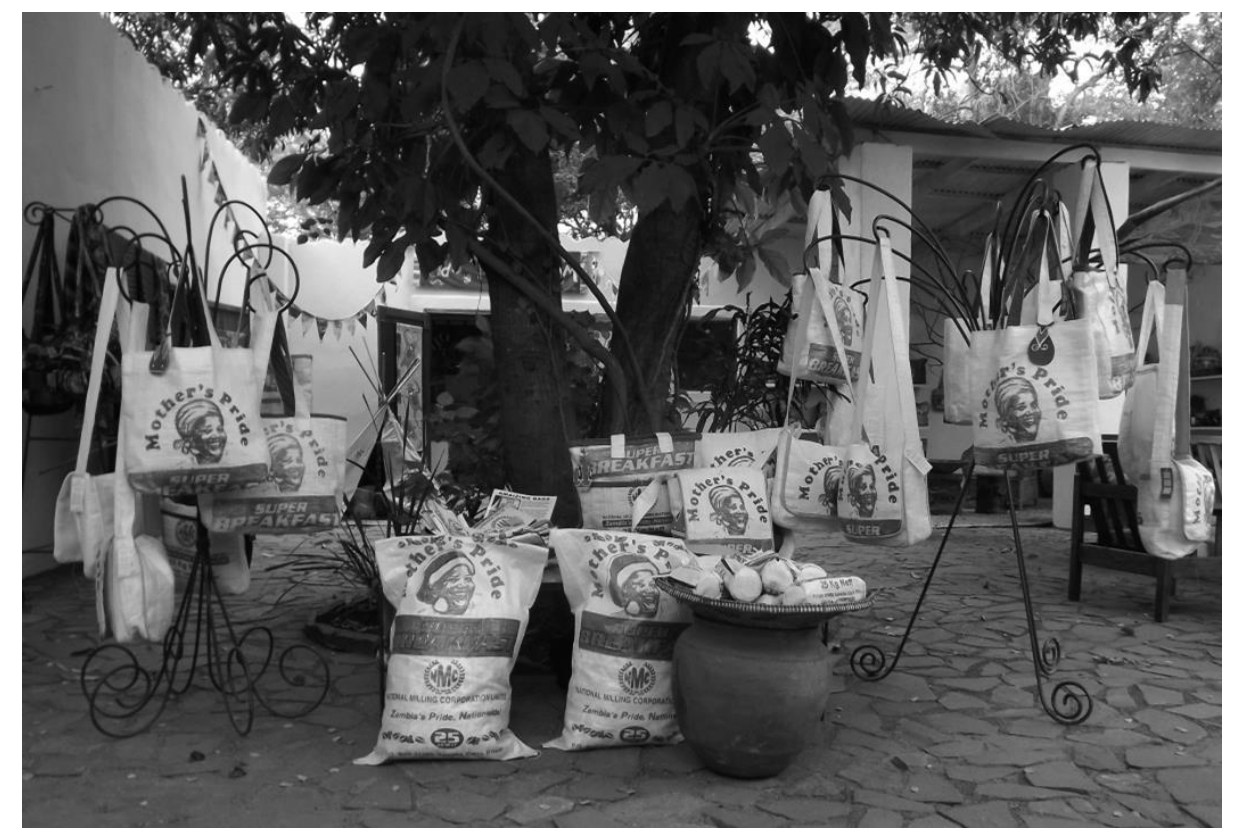

Fig. 1 Bags produced from recycled maize sacks made by Tribal Textiles at their Mfuwe workshop. Income generated from their sale is donated to the local charity Project Luangwa

They have over 100 staff, and are a major local employer. Locally many more people are supported directly and indirectly through employee wages, wage spending and company procurement. They also support local services through charitable giving and provide business opportunities for local micro entrepreneurs. Viewed more explicitly through a lens of social exclusion those directly employed by Tribal Textiles and their households benefit from an increase in income, which can enable them to better access health and education services. They may also be better able to purchase goods and participate in local economies, while additional livelihood opportunities can be generated, for example wages generating extra capital which can be used to start small businesses. Formal employment with a regular wage income can improve a household's ability to save, 
improving resilience to shocks. Positive change can also occur in household relationships and power dynamics (when women become the main or more significant earners). From a capabilities perspective Tribal Textiles helps reduce the exclusion from employment opportunities of rural BoP communities and households in the South Luangwa area, as well as providing scope for addressing the wider deprivations they experience. The fair trade dimension to the enterprise's work also helps to ensure inclusion/incorporation on more favourable terms. Tribal Textiles is a for profit enterprise with a strong social ethos, operating using a non-profit maximising fair trade approach. These cumulative characteristics problematize attempts to define it (as a social enterprise or traditional business) and at a wider level illustrate the complexity and ambiguity surrounding the nature of social purpose venturing in Africa.

Inclusion as consumers.

In the second channel social purpose ventures engage with the BoP as consumers of products, as illustrated by the for-profit environmental business Cookswell Enterprises, which produces, markets and sells innovative energy efficient charcoal cook stoves (see Fig. 2) and ovens to a range of customers, including the BoP, across Kenya and internationally. The Cookswell story began in 1982 when Kenyan Dr Max Kinyanjui started work designing energy efficient stoves (jikos), with support from the World Bank and national organisation Kenwood. As part of the funding for this project, there was provision for the setting up of a company, Wood Energy Technologies, and the training of technicians (fundis) in jiko making. The success of Dr Kinyanjui's work in Kenya, led to him undertaking similar activities with the World Bank in Malawi during the late 1980s, and in Tanzania in the early 1990s. In the early 2000s Dr Kinyanjui's son, Teddy Kinyanjui returned from overseas study and began working in the business. Identifying limitations in company capacity relating to marketing and distribution, Teddy established Cookswell Enterprises as a separate company to address these deficiencies. Teddy continues his late father's work, and acts as a leading advocate and practitioner for sustainable "seed-toash" cooking (Littlewood and Holt, 2012).

In line with BoP 2.0 approaches, the innovative sustainable design of the Cookswell products reduces charcoal use in cooking, saving customers money whilst also helping to limit tree cutting and preserve Kenya's forests. This small environmental enterprise is also active in tree planting, as part of its commitment to a sustainable cycle of cooking in Africa, and has started selling indigenous multi use tree seeds in small packets focussing on BoP customers, encouraging customers to grow their own fuel source in their smallholdings and plots of land.

A variety of potential benefits are identified stemming from Cookswell's products and activities across economic, wellbeing, opportunity and relational dimensions. For example reduced energy bills may mean more money is available for food, health and education costs, while household members particularly women are also exposed to fewer particulates in cooking and potentially have more income within households. Viewed in 
terms of social exclusion, capability and deprivation more specifically BoP purchases gain access to healthier and more nutritious means of cooking, through tree planting they can also develop long term household energy security, while increased income is useful in addressing other deprivations.

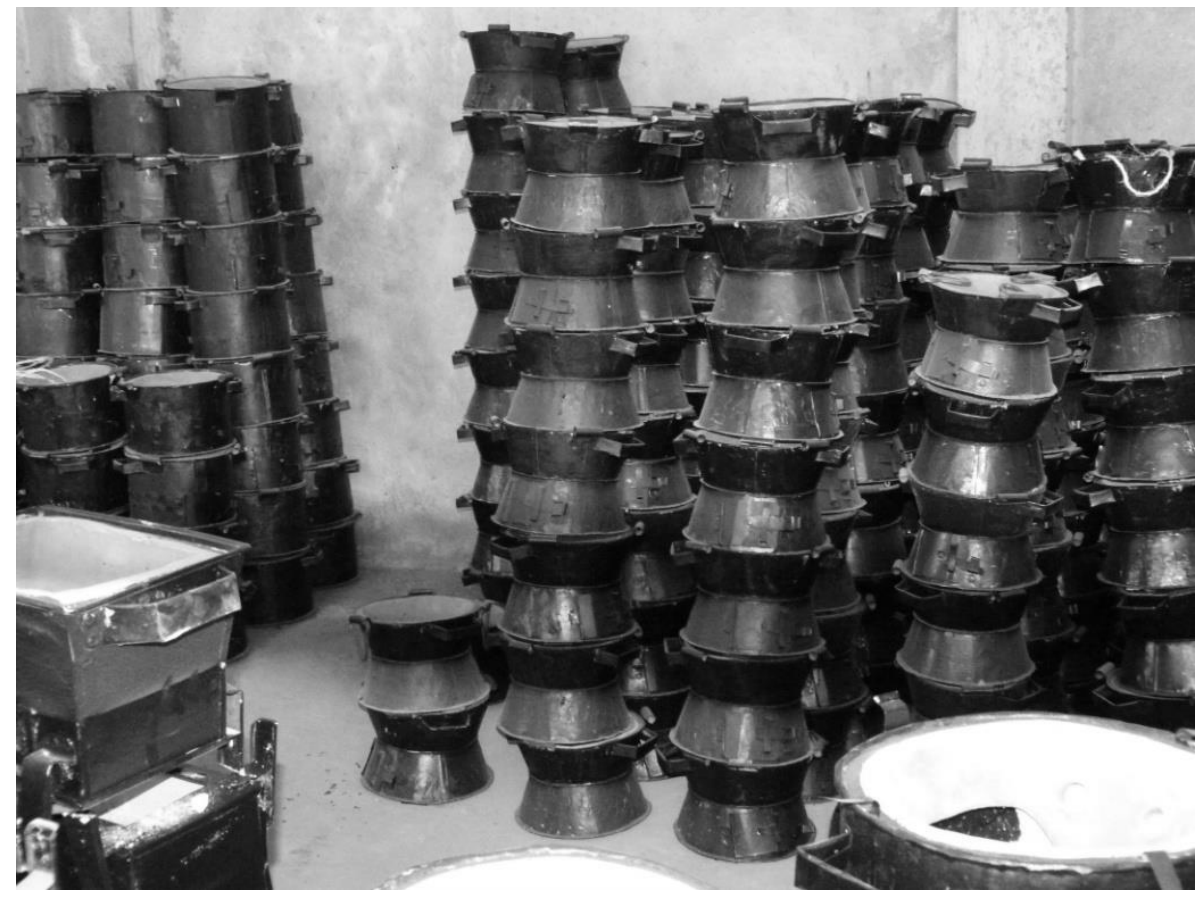

Fig. 2 Innovative energy efficient charcoal cook stoves produced by Cookswell/ Musaki

Enterprises and sold to the rural BoP along with small packets of multiuse tree seeds

Inclusion as producers.

Illustrating inclusion through the production of goods, the Mumwa Crafts Association is a membership association and non-profit enterprise based in Zambia's impoverished Western Province, working in the field of craft production, marketing and sale (see Fig. 3 for details of Mumwa's products). They were founded in 1994 under the leadership of a local Zambian community leader, Mr Kekelwa Mundia. Prior to Mumwa's establishment there had been a history of craft projects in Western Zambia initiated and supported by international donors and led by expatriates. Unfortunately these projects had frequently failed to become self-sufficient and had ceased either at the end of donor funding or upon the loss of expatriate staff. The failure of these previous projects generated scepticism on the part of international donors about the feasibility of any large scale craft project in Western Zambia. Various consultancy studies commissioned by the European Union and Irish Government amongst others in the early 1990s reinforced this perception, concluding that while such a project might be possible it would require substantial start-up capital and ongoing support from donors (Littlewood and Holt, 2013).

It was with this backdrop and in contrast to previous craft projects in Western Zambia, that the Mumwa Craft Association was founded with limited capital and donor support by committed local people with the aim of using crafts as a vehicle for community 
development and poverty alleviation. Mumwa developed organically from the bottom-up building on the commitment and 'zeal' of its members. From its inception member participation and ownership of the organisation has been central to the way the organisation operates. The organisation now has over 3500 members, many of whom are BoP informal microenterprise craft producers living in remote rural communities. Mumwa facilitates market access for its members, supporting and providing livelihood opportunities, and increased household incomes. Mumwa sells products nationally and internationally with the surpluses generated used for community development activities, including building rural clinics and water wells. Positive social and poverty alleviation impacts stemming from their activities are recognised across a range of stakeholder groups, but particularly amongst craft producer members, their families and dependents. These groups often experience an increase in individual and household incomes which can be used to counter deprivations in access to food, shelter, education, health etc. Relational benefits may also occur, for example increased status for producers within households and communities. Western Province is Zambia's poorest region. It is economically and politically marginalised, with limited formal employment opportunities and private sector investment. The Mumwa Craft Association is thus an important actor at a regional level tackling rural marginalisation and underdevelopment.

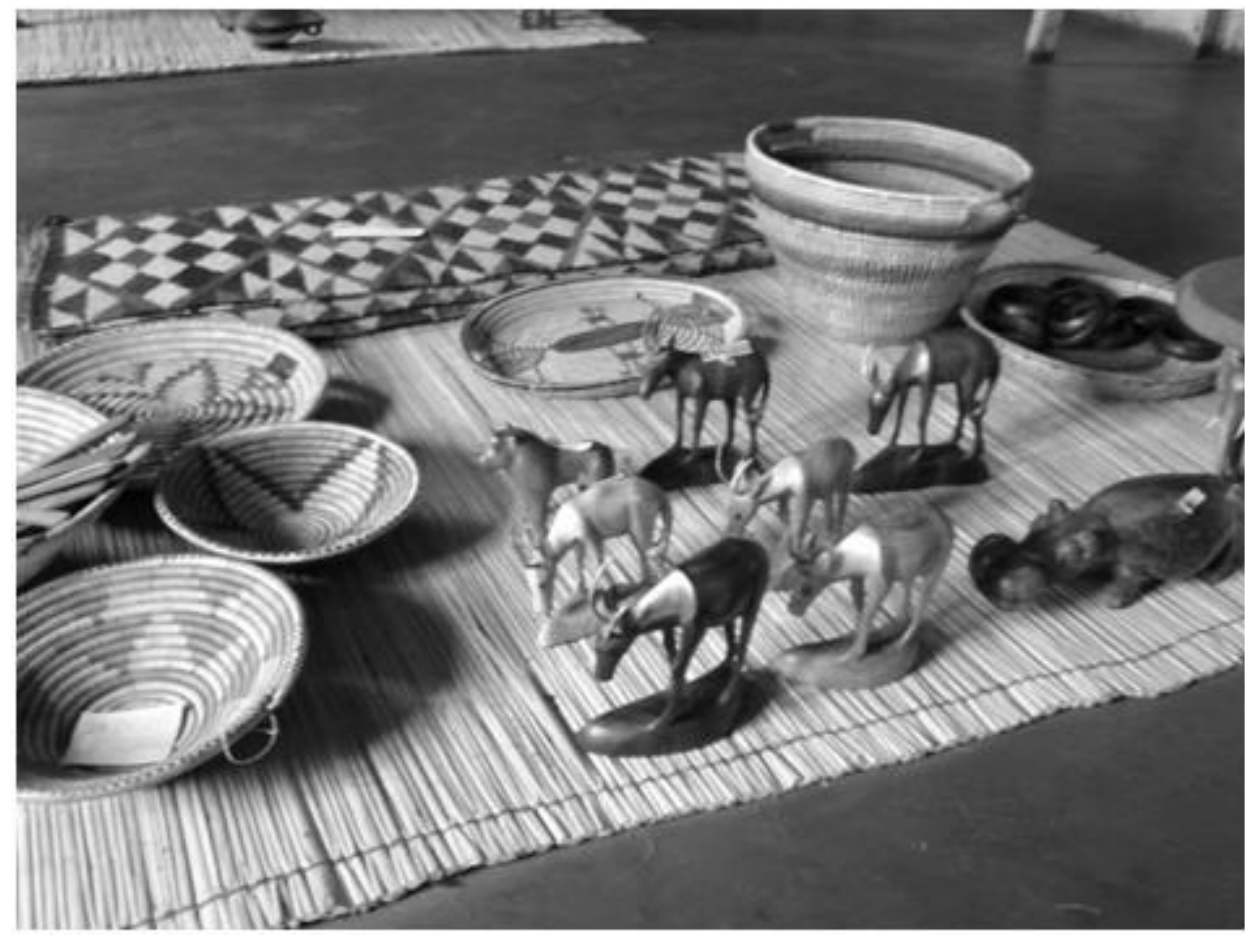

Fig. 1 Mumwa Craft Association Products

Social purpose ventures can also positively include the poor as producers of commodities, particularly agricultural. For example Eco-MICAIA and the Mozambique Honey Company purchase honey from BoP producers who have been provided with training in beekeeping, and given loans for the purchase of hives. The Mozambique Honey Company pays producers a premium price for their honey, and guarantees to purchase honey 
produced using non-environmentally destructive techniques. This intervention facilitates market access, while the additional income producers' gain can be used to address capability deprivations and failures.

Eco-MICAIA is a Mozambique registered social enterprise, developed as part of the family of initiatives by the British charity MICAIA UK. The Mozambique Honey Company was established in 2010 through a tripartite arrangement involving V\&M Grain Co, the Honey Producers Cooperative and Eco-MICAIA. Eco-MICAIA's role within the MICAIA family is to help communities and local people gain better access to local markets and to secure a stake in owning and managing successful enterprises. It also provides mission-related services to funders, investors, NGOs and communities. Any net profits made by EcoMICAIA are used to help sustain the MICAIA Foundation's core programmes. Eco-MICAIA aims to show that community economic development does not have to be about smallscale 'income generating projects'. Instead it can be about serious investment in viable businesses with potential to grow and to create lasting opportunities for local people. Eco-MICAIA's founding Directors are Milagre Nuvunga and Andrew Kingman.

Inclusion as entrepreneurs.

In this channel the BoP are included as micro entrepreneurs. MNC-led examples including VisionSpring's 'vision entrepreneurs' and ITC's E-choupal entrepreneurs (Hart and London, 2005). In our case examples, both Tough Stuff Solar and EcoFinder Kenya utilise micro entrepreneurship development approaches involving the sale or rental of solar lights. Tough Stuff Solar operates across a number of African countries, where in collaboration with commercial and non-profit partners, it runs a micro enterprise 'Business in a Box' (BIAB) programme. In this programme local Solar Village Entrepreneurs (SVEs) are selected, they are equipped with a proven business model, and their efforts to build a profitable micro-business are supported. In the Toughstuff example the SVEs sell solar products to people in their communities, while in the EcoFinder Kenya case a rental approach is adopted (See Fig. 4). In both instances the initial cost of the lights is recouped by the organisation at a mutually agreed upon rate from the entrepreneurs.

These interventions have positive inclusion benefits for both micro-entrepreneurs and their customers and communities. For the entrepreneurs an additional livelihood and source of income is created which can facilitate participation in local economies, and allow them to address deprivations in health, education, nutrition etc. The low requirements for entry in terms of skill, initial capital outlay, time and physical labour also mean this livelihood is ideally suited for individuals and groups that may be constrained from other livelihood activities and opportunities, for example the elderly, people with disabilities, the sick, those with limited skills and education. For those purchasing or renting the lights it may enable them and their families to work in the evening i.e. children doing homework. There is also an inherent wellbeing component in having access to lighting. 


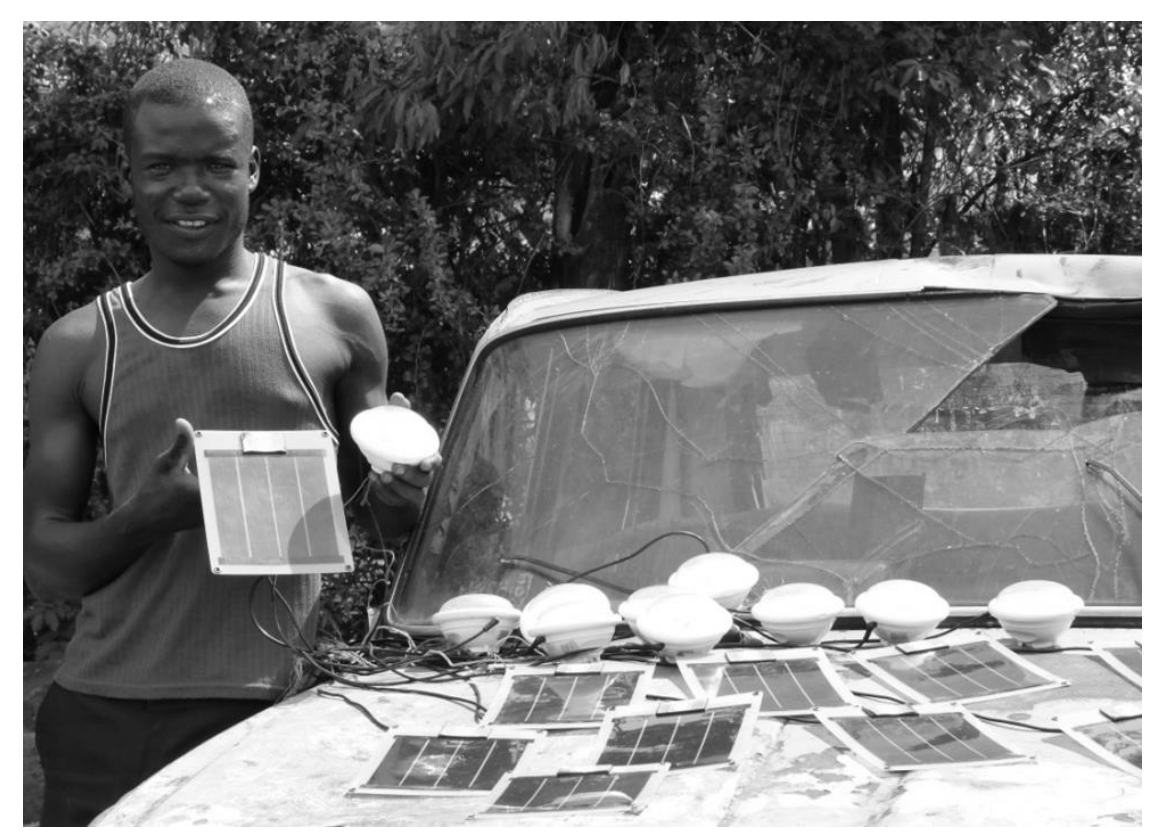

Fig. 2 A solar entrepreneur in Western Kenya. This entrepreneur was assisted in establishing his business by Eco-Finder Kenya

ToughStuff is an example of an international social enterprise headquartered in the UK. It was founded by Adriaan Mol and Andrew Tanswell in June 2008 as a social enterprise providing affordable solar-powered products for low-income people. ToughStuff started trading in Madagascar in July 2009 with 125000 units sold in the first two months. Following its success in Madagascar, ToughStuff moved into Kenya in July 2010. The company continues to grow and is expanding rapidly into neighbouring East African territories. ToughStuff is planning further expansion, initially into western and southern Africa, then internationally capitalising on on-going pilot programmes. In 2010, ToughStuff moved into emergency relief. Since the 2010 earthquake over 30000 ToughStuff emergency kits have been distributed in Haiti by the company's partner organisations.

In contrast Ecofinder Kenya grew from a community led initiative. It was formed in 1995 by a group of like-minded young people residing in Kisumu near Lake Victoria who shared a common desire to help their community tackle the many social, environmental and development problems facing it. Reflecting its formation by young people, EcoFinder Kenya was and remains particularly concerned with the challenges faced by young people. Initially EcoFinder Kenya was founded under the name the EcoFinder Youth Movement, however this name was deemed to have political connotations and was soon changed to the EcoFinder Youth Group. EcoFinder began primarily as a drama group undertaking social marketing for NGOs. Over time this drama group evolved into a registered self-help group and Community Based Organisation (CBO) for young people and expanded its areas of activity. EcoFinder Kenya recently changed is legal status and is 
now a registered Non-Governmental Organisation. Ecofinder Kenya uses solar lights supplied by ToughStuff in one of their livelihood initiatives.

Inclusion as service users.

The rural BoP frequently have limited access to services which are often of a low standard. There are a variety of ways in which social purpose ventures can engage with service provision for such groups. One approach is illustrated with reference to the Book Bus Foundation, a UK based not-for-profit and social enterprise which works to support education service provision in rural areas in Zambia and Malawi (and elsewhere in the world through other programmes).

The Book Bus Foundation was established in 2007 by Tom Maschler. Over the course of four decades in the publishing industry Tom nurtured the careers of many of the twentieth century's most esteemed authors, as well as coming up with the idea for the Booker Prize. His inspiration to start the Book Bus came after a trip to Zambia where he witnessed first-hand the role of literacy as a key life skill in uplifting a child from poverty to prosperity. Through Tom's hard work and the assistance of donors and supporters, including children's author and illustrator Quentin Blake who remains a charity trustee, the first Book Bus (Tiger) was purchased and equipped. After a send-off party in Trafalgar Square London, Tiger arrived at Southampton docks stocked with over 5000 donated books. It was at this stage that the Book Bus Foundation entered into partnership with the for-profit travel company VentureCo. VentureCo specialises in adventure travel and was set up in 1999 by David Gordon and Mark Davison. Each has over 25 years of experience driving overland trucks and running expeditions around the world. VentureCo brought a wealth of knowledge and expertise to this partnership, as well as relevant Air Travel Organisers' Licensing (ATOL). Through this partnership the present Book Bus volunteer programme was devised, which is administered through VentureCo as a strand of their wider portfolio of volunteer and adventure tourism activities (Holt and Littlewood, 2013).

The Book Bus Foundation operates mobile book buses which tour schools, hospitals and orphanages in rural areas, promoting reading to children who would otherwise have little or no access to books. In addition to providing a mobile library service, on-board volunteer crews, who pay to travel with the Book Buses sustaining its activities, engage with children and teachers to promote literacy. Since its inception the Book Bus Foundation has also donated over 39,000 books to schools in Africa.

In the Mumwa Craft Association case study they invest some of their surpluses in supporting local health services, for example providing funds to build an additional maternity room at the Mabumbu rural health clinic. This more philanthropic interaction with service provision was encountered in other cases studies. Finally social entrepreneurship approaches may be applied to service delivery, whereby ventures provide services such as water, electricity, and sanitation at a low price suitable for BoP 
markets. Alternatively BoP segments may be assisted in developing their own local service delivery solutions. For example EcoFinder Kenya helps households in Lake Victoria wetland communities to pay for the construction of 'eco-san' compostable toilets (see Fig. 5). These toilets have positive benefits in terms of health and sanitation, food security through the production of fertilizer, human wildlife conflict as farmers are less likely to send cattle into Lake Victoria mangrove swamp areas to graze where they come into conflict with wildlife, and finally in terms of dignity and freedom from shame.

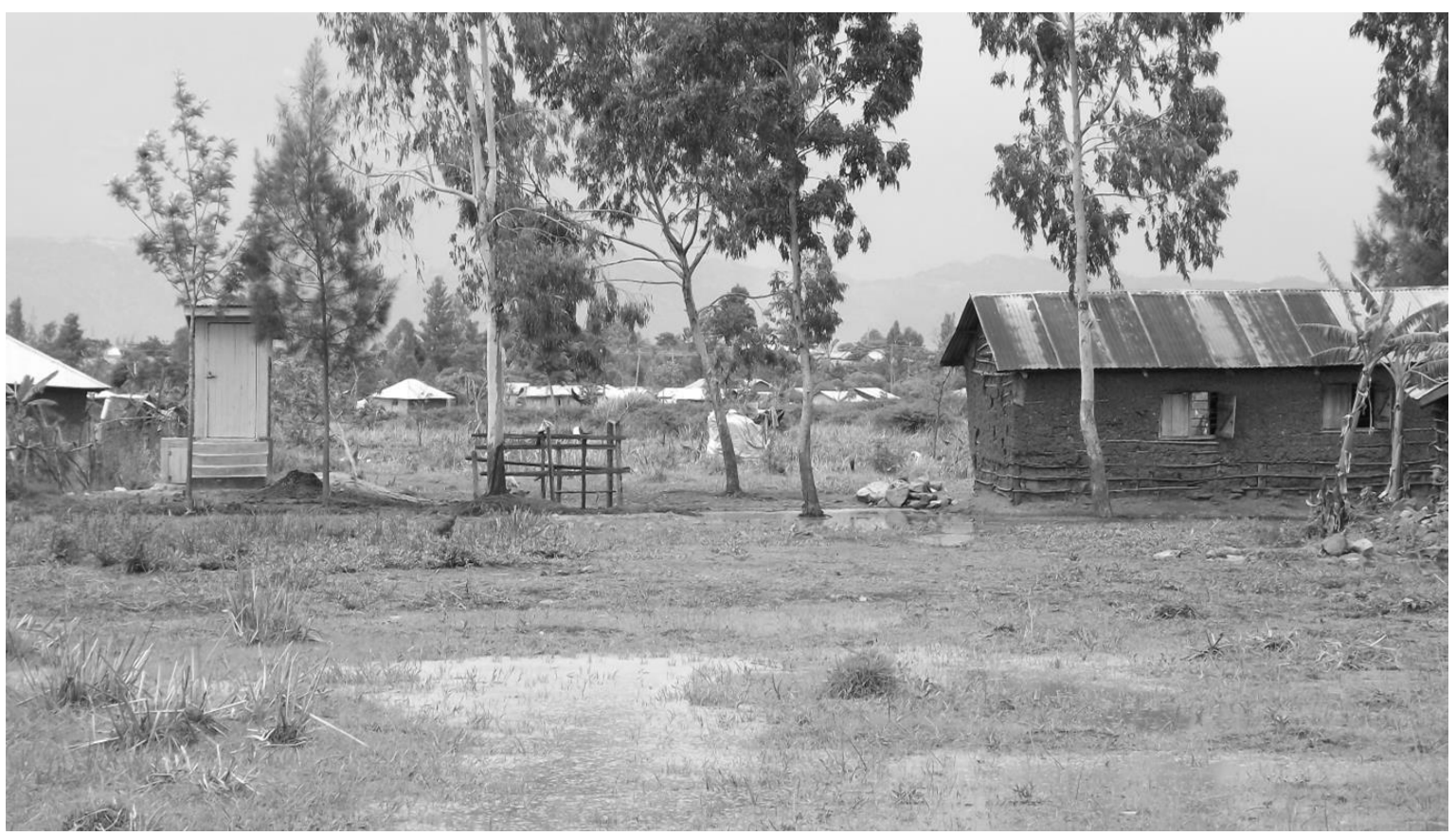

Fig. 5 'Eco-san' toilet in Lake Victoria wetland household Inclusion as shareholders.

In this final channel the rural BoP gain inclusion through shareholding in a social purpose venture. This can be illustrated by the Mozambique social enterprise Eco-MICAIA, which works with communities and private sector partners on a number of inclusive business ventures. Their Mozambique Honey Company is a good example of this approach, whereby almost 5000 rural BoP honey producers are organised into cooperatives with a $45 \%$ shareholding in the business. These honey producers receive profit dividends, and through their representatives have input in company decision making. Eco-MICAIA also works with communities in the Chimanimani Conservation Area on an eco-tourism venture, where through the Associação Kubatana Moribane these communities have a shareholding in the Ndzou Camp.

The six inclusion channels identified are not mutually exclusive. A good example of this is the Mezimbite Forest Centre, a social purpose venture based in central Mozambique producing high quality crafts for export and with a strong focus on environmental sustainability. The Center was founded in 1994 by Allan Schwarz, an architect, environmentalist and former teaching fellow at MIT, and gained formal legal status in 1996. Mezimbite works to eliminate poverty in forest communities by providing sustainable economic alternatives that protect and restore the forest ecosystem. They 
provide employment opportunities for members of the rural BoP, while also purchasing agricultural produce from local producers, and providing livelihoods training to local households in areas like honey production and agro-forestry.

The six channels discussed are also not exhaustive; there are undoubtedly other channels through which social purpose ventures contribute to tackling rural social exclusion. Moreover the potential for social purpose ventures to negatively impact on inclusion, or for adverse or unfavourable incorporation must also be recognised. In the following section, drawing upon the case examples, some common characteristics of successful social purpose ventures are identified from the cases.

\section{Characteristics of successful rural social purpose ventures}

Intervening, Integrating and Innovating for Environmental Sustainability.

Across the cases, environmental sustainability was encountered as a key theme informing the operational practices of rural social purpose ventures. In some instances it was also a central component of their development interventions, whilst in others the products or services they sold were environmental in nature. In a number of cases operating in a way that was environmentally sustainable was considered key to long term venture survival. For example in the case of the Mumwa Crafts Association, education and outreach work was undertaken with craft producers encouraging tree planting, and the uptake of techniques for the sustainable utilisation and harvesting of natural resources in craft production. In interviews with senior staff the example of a Zimbabwean based social purpose venture producing craft products from bamboo which had collapsed after two years through overuse of local natural resources was cited as a cautionary tale. Similarly the Mezimbite Forest Centre, which produces high quality crafts from indigenous Mozambican hardwoods, has integrated a large scale tree planting programme into its operations.

Both ToughStuff Solar and Cookswell Enterprises innovate for environmental sustainability through their products. In the case of Cookswell the business developed following a World Bank funded programme aimed at creating energy efficient stoves which could be sold to the BoP. The strong green credentials of the company and the accredited status of its products give Cookswell an advantage over competitors, as does the inclusion of tree seeds with every purchase aimed at encouraging positive environmental behaviour change. In Tough Stuff Solar's case, a concern for environmental sustainability, alongside meeting the need for appropriate context specific lighting technologies, is central to its business model.

For many of the case study ventures being green, be that organic honey or products made from sustainably sourced timber, added value, this was particularly the case where they were selling internationally. Finally for some of the ventures addressing environmental sustainability concerns was a central component in their community development interventions. For example the holistic approach adopted by EcoFinder 
Kenya in its work with communities in the Lake Victoria wetlands, recognising the intersection of environmental sustainability with social and economic development and poverty alleviation efforts.

\section{Participation, Embeddedness and Native Capability.}

In recent years there has been recognition of the need for the co-creation of value, with the poor included in venture design and product development, and for initiators of BoP programmes to engage with the BoP as partners rather than simply viewing them as potential customers or producers (London and Hart, 2004; Hart 2005; London, 2007). Listening to and engaging with the BoP in more meaningful, inclusive and equitable relationships was a characteristic also observed amongst our rural social purpose venture case studies.

An example of this are the inclusive business ventures initiated by the social enterprise Eco-MICAIA, where for instance in the case of the Mozambique Honey Company, producers have input through their representatives in company level decision making. In the Binga Camp ecotourism venture meaningful dialogue with the community also occurs through the Associação Kubatana Moribane. Utilising a slightly different approach the Book Bus Foundation Zambia has run workshops with local teachers, school principals, and wider local education representatives, with the aim of building local capacity but also acting as a forum for programme design and development, and to ensure that the activities of the Book Bus adds real value to education provision. In the Mumwa Craft Association, and some of the other case studies, participation is further married with accountability to the BoP. All Mumwa members pay a relatively nominal annual fee to the Association which is used for programme activities and for administration. The Association then has an Annual General Meeting (AGM) where the members are represented by elected craft group leaders, and at these meetings Mumwa's board is held accountable to the members, with the management team in turn accountable to the board.

The Mumwa case study is also illustrative in demonstrating the benefits and importance of leveraging local or native capacity, and that ventures are embedded in local communities. Before Mumwa's establishment in 1994 there were numerous failed attempts to set up craft project ventures in Zambia's Western Province. However Mumwa was founded 'bottom up' with almost no capital funding and under local leadership. Mumwa takes its name from a particularly resilient tree used in craft production, and it was Mumwa's local embeddedness, the capacity and long-term commitment of its local staff to mobilise resources and leverage relationships that have been so integral to its survival over time. Although this is not to suggest that internationally led social purpose ventures cannot achieve such local embeddedness, or that targeted support by international donors and development actors have not played an important role in Mumwa's success and growth. Overall Mumwa's experience 
suggests the benefits of complementary multi stakeholder partnerships bringing together organisations with different skills, knowledge and competencies.

Outlook and Orientation, Business Fundamentals and Market Selection.

The average age of the case study ventures is 16 years. The oldest has existed albeit in various guises for 31 years, the youngest for 5 years. Another 4 ventures are around 20 years old. These are mature social purpose ventures. They have survived and flourished because of the factors mentioned previously such as their recognition of environmental sustainability concerns and local embeddedness, participation and utilisation of native capacities. However they have also: selected their markets well; are outward and in some instances internationally orientated; have developed complementary linkages with MNCs and major retailers (in some cases this has entailed entering into supply chains, in others it has taken the form of more philanthropic corporate social responsibility type interactions); and finally they have got their business fundamentals right moving away from grant or donor funding to be more self-sufficient through trading.

The success of the case study ventures in selecting their markets, and the basis on which they compete, can be illustrated with reference to craft producers like Tribal Textiles, the Mezimbite Forest Centre and the Mumwa Craft Association. The former two businesses in particular produce unique, high value products for sale to domestic and international customers. They differentiate from competitors on the basis of quality and uniqueness, as well as the wider social and environmental story around production and sale that allows for a social premium. The Mumwa Crafts Association is also working with international partners to develop more advanced products integrating multiple materials which can be sold for a higher price.

Cookswell Enterprises competes with domestic and international low cost competitors in formal and informal economic spaces on the basis of its product quality and positive environmental credentials. Cookswell has also been successful in getting its products in larger regional retailers and supermarkets. Several other case enterprises also have supply contracts with larger retailers at domestic, regional and global levels. The regular bulk purchasing associated with such contracts can be critical in venture growth. In the case of the Book Bus Foundation its interactions with MNC publishers have been more philanthropic, taking the form of large scale mutually beneficial book donations. Despite frequently operating in quite remote and marginal rural regions and communities these case study ventures are often well networked internationally both in terms customers but also wider supporters and advocates. These networks and relationships are drawn upon aiding business growth but also during times of crisis.

Finally amongst the case study ventures, and particularly those older and more environmentally oriented, importance was attached to operating efficiently and effectively as enterprises, and on being self-sustainable through trading. Income generation was not an afterthought or added extra but a central concern. In interviews 
scepticism was often encountered about charities and traditional NGOs engaging in trading activity and moving into social venture spaces, with one entrepreneur outlining his fear of appearing "too NGOish" with repercussions for the reputation of his business, and relationships with customers, suppliers and wider stakeholders. Amongst the cases many of the founder entrepreneurs came from more traditional business backgrounds, bringing this knowledge, skills and experience to bear in addressing a social and or environmental problem. Some scepticism was also encountered in interviews with entrepreneurs about development practitioners setting up social purpose ventures. However entrepreneurs were willing to recognise some of their own limitations and gaps in knowledge and capacity, especially when it came to the social and development side of their venture. In general the case study ventures had achieved a high level of income through trading activity, with benefits for resilience and also that they were not dictated to by international donors and external actors, or had to invest constant time and resources bidding for funding with potential danger for mission drift. This kind of funding and activity was often an added extra, for example the Mumwa Craft Association's work with the Zambian Government constructing rural water wells.

\section{Implications for Policy, Practice and Research}

This chapter adds to knowledge in the field of social purpose venturing in Africa and wider developing world environments, helping to address the gap in empirical research on this subject. Discussions in the chapter contribute to questions and debates about the definition and nature of social purpose ventures in Africa. They furthermore shed light on interactions between social purposes ventures and the BoP, and highlight how such ventures can contribute to addressing social exclusion in its various guises and sustainable development in rural households, communities and regions. This chapter is also unusual in its use of multiple rural venture case studies, across a number of countries. Additionally this chapter has implications for research in terms of the themes for future exploration such as; fostering and encouraging local embeddedness and participation; explicitly mapping and measuring social inclusion impacts of social purpose ventures; and the influence of founder entrepreneurs characteristics and the wider context in which start-up processes occur influencing the success and survival of such ventures.

This chapter also has various implications for practice. In particular from the case examples, various common characteristics or traits which appear to factor into the success of social purpose ventures are identified. Notably these are: engagement with environmental sustainability concerns; the benefits of local embeddedness, participation and utilising native capabilities; the importance of outward and often international orientation for success and up-scaling, of developing complementary links with MNCs and larger businesses; and more generally getting the business fundamentals in place with self-sufficiency through trading recognised as a key objective. 
Alongside the stories and insights presented on successful enterprise characteristics, this chapter also describes better practice examples of how social purpose ventures can operate and engage with the BoP contributing to positive social inclusion. The social exclusion and capabilities lens outlined may also be useful as a framework for social purpose ventures to understand their positive and negative impacts.

Finally this chapter provides insights and has implications for policy. It illustrates the potential of social purpose ventures for addressing social exclusion, poverty and disadvantage in rural regions and communities, presenting examples of up-scaled initiatives, and adding impetus to the case for more appropriate policies, legislation and support for such ventures as vehicles for rural development. This applies to both state actors in the developed and developing worlds, and wider international institutions. This chapter presents a snapshot of the complex and heterogeneous landscape of social purpose venturing in Africa. It illustrates the great potential of social purpose venturing for addressing issues like social exclusion, but in a broader sense contributing to development on the Continent and globally. Nevertheless many questions remain, particularly in relation to whether, and if so how, the potential of social purpose venturing as a catalyst for sustainable development will be realised.

\section{References}

Beall, J., \& Piron, L.H. (2009). DFID Social Exclusion Review. London: Overseas

Development Institute. Retrieved from

<http://dspace.cigilibrary.org/ispui/handle/123456789/22869>

Bird, K., Hulme, D., Moore, K., \& Shepherd, A. (2002). Chronic poverty and remote rural areas. Chronic Poverty Research Centre (CPRC) working paper no 13. Birmingham: International Development Department, University of Birmingham, Retrieved from <http://r4d.dfid.gov.uk/PDF/Outputs/ChronicPoverty_RC/13Bird_et_al.pdf>

Bronstein, D. (2004). How to change the world: social entrepreneurs and the power of new ideas. London: Penguin Books.

Du Toit, A. (2004). 'Social exclusion' discourse and chronic poverty: a South African case study. Development and Change, 35(5), 987-1010.

de Hann, A. (2001). Social exclusion: enriching the understanding of deprivation. Sussex: Poverty Research Unit, University of Sussex. Retrieved from $<$ http://www.sussex.ac.uk/cspt/documents/issue2-2.pdf>.

Francis, E. (2006). Poverty: causes, responses and consequences in rural South Africa, CPRC working paper no. 60. London: Development Studies Institute, London School of Economics, Retrieved from <http://r4d.dfid.gov.uk/PDF/Outputs/ChronicPoverty_RC/60Francis.pdf>.

Garette, B. \& Karnani, A.G. (2010). Challenges in marketing socially useful goods to the poor, California Management Review, 52(4), 29-47. 
Hart, S.L. (2005). Capitalism at the crossroads: the unlimited business opportunities in serving the world's most difficult problems. Upper Saddle River, NJ: Wharton School Publishing.

Hart, S. L., \& London, T. (2005). Developing native capability: what multinational corporations can learn from the base of the pyramid. Stanford Social Innovation Review, $3(2), 28-33$.

Hickey, S. \& du Toit, A. (2007). Adverse incorporation, social exclusion and chronic poverty CPRC working paper no. 81. Manchester: Chronic Poverty Research Centre, University of Manchester. <Retrieved from http://www.chronicpoverty.org/uploads/publication_files/WP81_Hickey_duToit.pdf> Holt, D. \& Littlewood, D. (2013). The Book Bus "Improving children's lives one book at a time". The Trickle Out Africa Project case study series: No.2. February, ISSN 2052-0026 IFAD (2010). Rural Poverty Report 2011. Quintily, Rome, Italy: International Fund for Agricultural Development.

Karnani, A. (2007a). The mirage of marketing to the bottom of the pyramid: how the private sector can help alleviate poverty. California Management Review, 49(4), 90-111.

Karnani, A. (2007b). Microfinance misses its mark. Stanford Social Innovation Review, Summer, 34-40.

Karnani, A. (2009). Romanticizing the poor. Stanford Social Innovation Review, Winter, pp. 38-43.

Kerlin, A. (2009). Social enterprise a global comparison. University Press of New England. Lenoir, R. (1974/1989). Les Exclus: Un Francais sur Dix. 2nd. ed. Paris: Editions de Seuil. Littlewood, D \& Holt, D. (2012). Cookswell Enterprises "Save Money, Save Energy, Save our Forests and Eat Well". The Trickle Out Africa Project case study series: No.1. December, ISSN 2052-0026

Littlewood, D. \& Holt, D. (2013). The Mumwa Crafts Association Community Development through Craft Production". The Trickle Out Africa Project case study series: No.3. April, ISSN 2052-0026

London, T. (2007). A base-of-the-pyramid perspective on poverty alleviation working paper. Michigan: William Davidson Institute/Stephen M. Ross School of Business, University of Michigan. Retrieved from <http://www.erb.umich.edu/News-andEvents/colloquium_papers/BoP_Perspective_on_Poverty_Alleviation_London\%20(UND P).pdf>

London, T. (2009). Making better investments at the base of the pyramid. Harvard Business Review, 87(5), 106-113. 
London, T., \& Hart, S.L. (2004). Reinventing strategies for emerging markets: beyond the transnational model. Journal of International Business Studies 35, 350-370.

London, T., \& Hart, S.L. (2010). Next generation business strategies for the base of the pyramid: New approaches for building mutual value. FT Press.

Manuamorn, O.P. (2007). Scaling up micro-insurance: the case of weather insurance for smallholders in India. Agriculture and Rural Development Discussion Paper 36.

Washington: The International Bank for Reconstruction and Development/The World Bank. Retrieved from <http://www-

wds.worldbank.org/external/default/WDSContentServer/WDSP/IB/2007/10/31/0003106 07_20071031162024/Rendered/PDF/412430INOScali1roinsurance01PUBLIC1.pdf>

Masendeke, A., \& Mugova, A. (2009). Zimbabwe and Zambia. In Kerlin J. (Ed.), Social enterprise: A global comparison. (pp. 114-138).

Munoz, S.A. (2010). Towards a geographical research agenda for social enterprise. Area, $42,302-312$.

Prahalad, C.K., \& Hart, S.L. (2002). The fortune at the bottom of the pyramid. Strategy and Business 26, 54-67.

Prahalad, C.K. (2004). The Fortune at the Bottom of the Pyramid. Wharton School Publishing.

Rittel, H., \& Weber, M. (1973). Dilemmas in a general theory of planning. Policy Sciences, 4, 155-169.

SEED \& IISD (2009). The SEED Initiative. Retrieved from < http://www.seedinit.org/>

Sen, A. (2000). Social exclusion: concept, application and scrutiny, Social Development Papers no. 1. Manila, Philippines: Office of Environment and Social Development Asian Development Bank. Retrieved from <http://housingforall.org/Social_exclusion.pdf > Silver, H. (1994). Social exclusion and social solidarity: three paradigms IILS discussion papers no. 69. Geneva: ILO.

Simanis, E., \& Hart, S.L. (2008). The base of the pyramid protocol: Toward next generation BoP strategy (2nd ed.). New York: Center for Sustainable Global Enterprise.

Thompson, J. \& Doherty, B., (2006). The diverse world of social enterprise: a collection of social enterprise stories. International Journal of Social Economics, 33(5/6), 399-410

Wheeler, D., McKague, K., Thomson, J., Davies, R., Medalye, J., \& Prada, M. (2005). Creating sustainable local enterprise networks. MIT Sloan Management Review, 47(1), 33-40.

\section{Acknowledgments}

The authors would like to acknowledge the financial support of the Economic and Social Research Council (ESRC grant reference RES-061-25-0473). We would also like to thank all 
the participants in our interviews and focus groups and the access granted to us by the case studies. All views expressed in this article are those of the authors only. Further information http://www.trickleout.net/index.php/casestudiesmenu 